\author{
A.I. Skripnikova \\ Al-Farabi Kazakh National University, Kazakhstan, Almaty, e-mail: sai.kz@mail.ru
}

\title{
WHAT EVERY JOURNALIST SHOULD KNOW ABOUT THE CHROMA KEY
}

The article is a review of modern foreign literature about Chroma key. Everything is described in detail: from contradictory terminology to the history of the formation and development of this technology. Unfortunately, in Kazakhstan there is no educational literature on this topic, intended for future or already working journalists. The purpose of this article is to adapt foreign information and fill the gap with its help. The scientific significance of the work directly follows from the lack of such research in the Republic of Kazakhstan. The methodology is based on the monitoring of foreign publications, their analysis and layout, using such an applied method as a review. The use of Chroma key significantly reduces the cost of producing media content and helps quickly go through the post-production stage. In addition, Chroma key allows to connect objects that cannot exist next to each other in reality in one frame. The results of the review prove that Chroma key opens up additional opportunities for creativity, in particular for journalistic stand-ups. The main problems arise when graduates of journalism faculties at the workplace for the first time encounter the fact that they themselves must organize shooting with Chroma key. Even if a separate technical specialist is included in the editorial staff, each member of the shooting crew must know the basics of working with the so-called "green screen" or on the "greenback" (journalistic slang). The value of the work is that the author offers a brief step-by-step instruction for any journalist who wants to learn a new technology. The journalist must understand and even "feel" the difference between the dimensional types of Chroma key: stand, wall, stage, room and corner. The journalist should know when it is possible to use blue cloth; what you need to have in case of unplanned combined shooting, why do you need a white bed sheet, tennis balls on the fishing line, red crosses made from electrical tape and what is best suited from clothes. The practical significance of the work's results lies in the fact that the described skills and knowledge can significantly expand the creative and technical capabilities of a journalist, accordingly, improve his qualifications.

Key words: journalism, Chroma key, Green Screen, keying, digital technologies.

\section{А.И. Скрипникова}

Әл-Фараби атындағы Қазақ ұлттық университеті, Қазақстан, Алматы қ., е-mail: sai.kz@mail.ru

\section{Әр журналист кромакей турахы не бікуі керек?}

Мақалада кромакей туралы қазіргі заманғы шетел әдебиеттеріне шолу жасалған. Қарамақайшылықты терминологиядан бастап, осы технологияның қалыптасуы мен даму тарихына дейін барлығы егжей-тегжейлі сипатталған. Өкінішке орай, Қазақстанда болашақ журналистер мен жұмыс істейтін журналистерге арналған бұл тақырыпта оқу-әдістемелік әдебиет жоқ. Бұл мақаланың мақсаты - шетелдік ақпаратты бейімдеу және оның көмегімен олқылықтардың орнын толтыру. Жұмыстың ғылыми маңызы Қазақстан Республикасында мұндай зерттеулердің жоқтығынан туындайды. ӘАістеме шолу сияқты қолданбалы әдісімен шетелдік жарияланымдарды бақылауға, олардың талдауы мен орналасуына негізделген. Кромакейді қолдану медиа-контент шығару процесінің өзіндік құнын едәуір азайтады және өндірістен кейінгі кезеңге тез өтуге көмектесеАі (бір клик). Сонымен қатар, кромакей шын мәнінде бір-бірінің жанында бола алмайтын нысандарды бір каАрға қосуға мүмкіндік береді. Шолудың нәтижелері кромекейдің шығармашылыққа, әсіресе журналистік стендапқа қосымша мүмкіндіктер ашатындығын Аәлелдейді. Негізгі мәселелер журналистика факультетін бітірушілер жұмыс орнында алғаш рет кромакеймен видео түсіруді ұйымдастыруы керек кезде туындайды. Редакция құрамына жеке техникалық маман кірсе де, түсіру тобының әрбір мүшесі «жасы^ экран» немесе «зелёнка» (журналистік сленг) деп аталатын жұмыс негіздерін білуі керек. Жасалған жұмыстың құндылығы - автор жаңа технологияны меңгергісі келетін әр журналист үшін қаламдық қысқа нұсқаулық ұсынады. Біріншіден, кәсіби терминологияны түсіну керек; журналист кромакейдің кеңістіктік формаларының (стенд, қабырға, сахна, бұрыш, бөлме, павильон) арасындағы айырмашылықты түсініп, «сезінуі» керек. Журналист көк матаны қандай жағдайларда қолданған дұрыс екенін білуі керек; «жасы^ экранда» жоспарланбаған түсірілім жағдайында өзіңізбен бірге алып жүруіңіз керек 
нәрсе; студияға не үшін ақ жайма керек, балық аулау сызығындағы теннис доптары, электрлік лентадан қызыл кресттер керек; сондай-ақ не киюге болады және не киюге мүлдем болмайды. Жұмыс нәтижелерінің практикалық құндылығы - мұндай дағдылар мен білімдер журналистің шығармашылық, және техникалық мүмкіндіктерін едәуір кеңейтеАі, сәйкесінше оның біліктілігін арттырады.

Түйін сөздер: журналистика, кромакей, жасыл экран, кеинг, сандық технологиялар.

\section{А.И. Скрипникова}

Казахский национальный университет им. аль-Фараби, Казахстан, г. А^маты, e-mail: sai.kz@mail.ru

\section{Что должен знать каждый журналист о кромакей}

Статья преАставляет собой обзор современной зарубежной митературы о кромакей. Подробно описано все: от противоречивой терминологии до истории становления и развития этой технологии. К сожалению, в Казахстане нет учебной китературы по Аанной тематике, предназначенной А^я будущих или уже работающих журналистов. Целью Аанной статьи служит адаптация зарубежной информации и восполнение пробела в понимании новой технологии с ее помощью. Научная значимость работы напрямую вытекает из отсутствия подобных исследований в РК. Методология базируется на мониторинге зарубежных публикаций, их анализе и компоновке, с применением такого прикладного метода как обзор. Использование кромакей значительно удешевляет процесс производства медиаконтента, помогает быстро пройти стадию пост-продакш (в один клик). Кроме того, кромакей позволяет соеАинять в одном каАре объекты, которые не могут существовать рядом Аруг с Аругом в реальности. Результаты обзора Аоказывают, что кромакей открывает дополнительные возможности Аля творчества, в частности Аля журналистских стендапов. Основные проблемы возникают, когда выпускники факультетов журналистики на рабочем месте впервые сталкиваются с тем, что сами должны организовать съемку с кромакей. Ааже если в редакционный штат входит отАельный технический специалист, каждый член съемочной группы должен знать основы работы на так называемом «зеленом экране» или на «зелёнке» (журналистский сленг). Ценность проделанной работы зак^ючается в том, что автор предлагает краткую пошаговую инструкцию Аля ^юбого журналиста, который хочет освоить новую Аля себя технологию. Прежде всего, необходимо знать терминологию; понимать и даже «чувствовать» разницу между пространственными формами кромакей (стенА, стена, сцена, угол, комната, павильон); знать, в каких условиях лучше использовать синюю ткань; что нужно иметь при себе в случае незапланированной съемки на «зеленом экране»; зачем в студии нужна белая простыня, теннисные мячи на ^еске, красные крестики из изоленты; а также что можно и что категорически нельзя налевать. Практическое значение итогов работы заключается в том, что описанные навыки и знания могут значительно расширить творческие и технические возможности журналиста, соответственно, повысить его ква^ификацию.

Ключевые слова: журналистика, кромакей, зеленый экран, кеинг, цифровые технологии.

\section{Introduction}

Today journalists can appear anywhere in the world without leaving the studio with a Chroma keying effect (Zeke, 2014). This is very convenient, and significantly reduces the cost of the process of producing media content. In addition, Chroma key allows to combine objects in a single frame that cannot really exist with each other, and this opens up additional opportunities for journalistic creativity. This technology has become very popular among young Kazakhstani journalists and bloggers. However, despite the huge number of examples of the use of so-called "Green Screen" (although this is not quite the right name, because the screen may also be another color) in the media space, few know the history and features of used technology. Such knowledges can significantly expand opportunities.
Chroma keys can be done in post-production or in real-time. Television programs such as news and entertainment shows use them a lot (MediaCollege. com). The first thing that came to the mind in connection with this technology was the weather forecast. Now the situation has changed, and Chroma key is widely used both in interviews and in analytical materials. With the renewal of cameras (the transition from film to digital) on all Kazakhstan television channels, this technology has been used more often than ever.

The main problems arise when graduates of journalism faculty at the workplace are faced with the fact that they themselves must organize shooting with Chroma key. As a rule, personal experience among graduates is absent. Of course, all students have experience in working in front of camera, but staff members organized the shooting in the 
training television studio. In real conditions, the journalist himself must control all aspects related to the applied technology. According to the list of tips from industry experts " 10 things every journalists should know" skills are on the first place (Marshall, 2013).

\section{Materials \& methods}

For the above reason, the decision to make a short review of the best articles about this technology and bring out some universal tips for Chroma key shooting was taken.

Therefore, this article is a review of publications about the technology. No materials of Kazakh origin on this topic were found. Only modern foreign literature is used. Nevertheless, due to its catholicity and the lack of any geographical restrictions or features in use, all methods are suitable for Kazakhstani media. Moreover, the country just adopts foreign technologies - does not invent and improve them. There is no industrial production of Chroma key in Kazakhstan, but absolutely all television channels, even municipal, use this technology by simply making Chroma key from cloth on their own. Prices for professional Chroma key in the Republic vary on average from 20,000 to 100,000 (transformer) tenge per unit (satu.kz).

\section{Results}

So, first of all, it is necessary to understand the terminology, because often students do not see any special differences in definitions, although they exist. Let's draw clear boundaries between the existing terms that describe the technology:

Green Screen: technically, this term refers to the colored background you want to make transparent and remove from your shot. This is usually a single colored backdrop, which can be any color, but is usually bright green because it is the color furthest away from human skin tones. Sometimes the term is used as a fit-all for the entire process of keying.

Chroma Key: this popular term goes hand-inhand with Green Screen. It's the actual technique of layering, or compositing two images based on color hues. Every color has a chroma range, hence where the terminology comes from (Yeager, 2019). Literally translated as "color key", from Greek $\chi \rho \omega ́ \mu \alpha$ - "color" - the technology of combining two or more images or frames in one composition, color electronic rear-projection, used on television and in modern digital film production technology. Using Chroma key, you can "remove" the background and "attach" an image or video through a video editor. Also in everyday life, the screen itself is called Chroma key, on the background of which shooting takes place (Voroisky, 2016). As follows from the above, differences between these two concepts are:

Chroma Key is the actual term while green screen is its common name.

Green screen uses a green backdrop while just about any color can be used in Chroma keying (Joan, 2012).

Among Kazakhstani journalists, the pronunciation of the analyzed technology, as always, is incorrect. They say "khromakey"; although correct will be "kromaki". Future journalists need to be taught to pronounce the name of the technology correctly already from the student bench.

There is another commonly used term - Chroma key wall.

Chroma key Wall is a lightweight green screen solution of portable design. The material of which it is made is heavy-duty, washable, non-wrinkle nylon spandex. The green screen cloth can be spanned around the modular aluminium fram. The stand easy and fast to set up and can be used at live events and studio projects where there is little space. Can be delivered with matching LED lights (Streamingvalley.nl).

It should be noted that the wall is one of the easiest version of Chroma key. In addition to the wall, there are several more options. Specifically: stand, wall, stage, room and corner. The main difference between them is the space needed for shooting.

As a rule, wider shots that capture person's entire body and action shots that require lots of movement will need a full green screen that also covers the ground, and maybe even the side of the shot. If this is the case, the screen should has no edges so that you can key in easily. You'll want to use a curved screen and drops without hard edges to the floor or to side walls (Yeager, 2019).

By the other words, if you plan to shoot only one journalist in a close-up shot, a small stand will be enough. If you need to shoot several people at full height, you need, accordingly, a larger space and another option of Chroma key. All of them are shown on the Pic. 1 


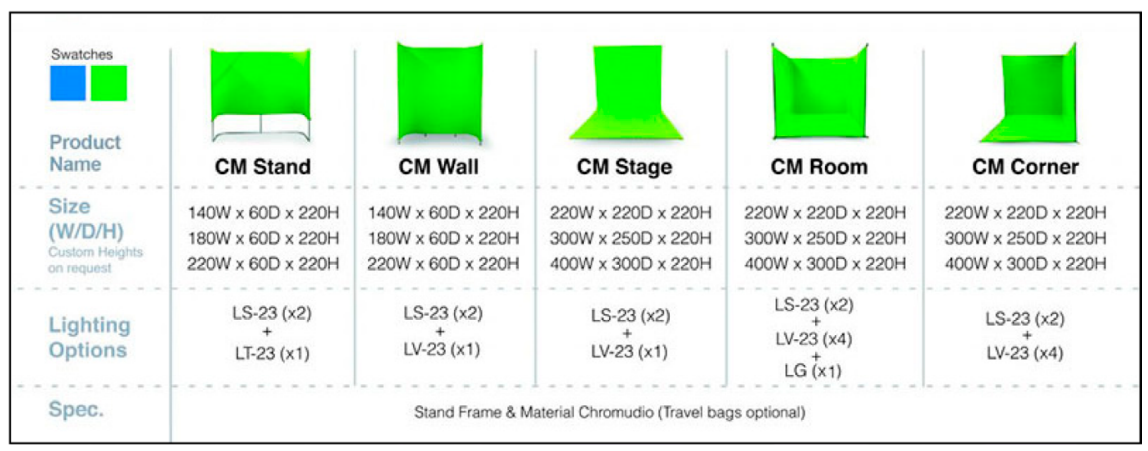

Picture 1 - Dimensional Chroma key options (Streamingvalley.nl)

Here we intentionally do not mention such an option as the pavilion, because, as a rule, it is not used in journalism (only in the cinema field, and in very multi-budget projects).

After all, we should proceed to the definition of the process itself.

Keying: this term is used to describe the process of removing the green screen background in postproduction using video editing software. When the green screen background has been keyed, it will be fully transparent. Then you can fill in that transparent area with a different image or video. The goal is to get the cleanest key possible, meaning there are no digital artifacts left on your image where the green screen was originally (Yeager, 2019).

As follows from the above data, even at the stage of the correct definition of technology, errors can occur. Often, in colloquial or professional speech, the boundaries between the definitions of the process itself, the cloth, as an integral attribute of the shooting, and the process that enters the post-production stage, sometimes are erased. Kazakhstani journalists often use the professional slang word "zelonka", which also designates the technology of shooting.

Another terminological discrepancy is observed in terms related to such shooting. There is no one scientific common name for the costumes that are used. They may be called: Green screen suits, Chroma key suits or VFX clothing. Interpretation possible in general terms.

A green suit is the same color as a green screen backdrop, making it easy to delete the people wearing them later during post-production. The green screen suit comes in a variety of sizes and covers the wearer from head to toe. The suits are usually close-fitting so that there will be few wrinkles or shadows; this will allow a person to be practically invisible in a shot when filmed against a green screen backdrop. Green screen suits are flexible for full range of motion, but the head is made of a thinner material, allowing users to breathe and see easily (Backdrop, 2013). It's very convenient for journalists to wear such suits. For example, you can record a stand-up to the opening of the museum in historical clothing without spending money and time looking for a real historical costume. Another example, talking about the statistics of heart diseases, a journalist can say the desired text while standing in the frame and during the editing stage you can make his heart beating. On the other hand, talking about the premiere of a new film, the head of a journalist can turn into the main character. The possibilities for creativity are becoming almost limitless. All popular clothing options are shown on the Pic. 2.

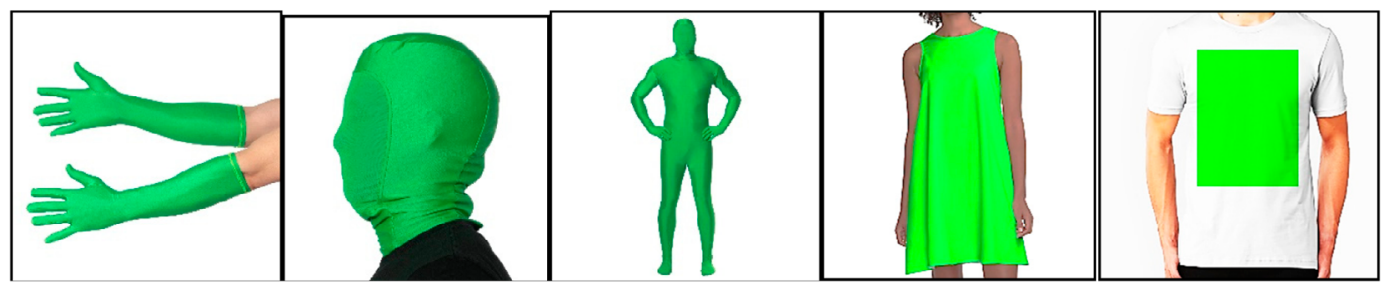

(Chromakeysuit.com \& Redbubble.com, 2020)

Picture 2 - Green screen suits and accessories 
After we have decided on the terminology used, let's return to the history of Chroma key and its modern transformation.

"The thief of Bagdad" was one of the first films based on Chroma key technology (in particular, it was used to shoot the appearance of the genie), developed in the early 1930 s by L. Dunn, who worked for "RKO Radio Pictures". During the creation of the film, L. Butler, who was responsible for creating innovative special effects for that time, significantly improved it and was subsequently awarded an Oscar for best visual effects (Higgins, 2017).

Massively green screens and blue screens become the keys to Chroma key in the 1970s. The use of blue or green screens as backgrounds Chroma key became widespread amongst all TV channels. The goal of that technology was to shoot the weatherman in the studio against a blue or green screen. Then they would delete the background color and insert various images, from maps to pictures, as well as city names and temperature (Driscoll, 2019). But that was long ago. Now this technology has become much easier to use. There is a huge amount of computer programs that allow users even with limited technical knowledge to create video content on a Green Screen. This, in turn, brought the technology to the consumer level.

In the past, the main color for chromakeying was blue. Beginning in the late 1970s, there was a slow industry flip-over to green-colored screens for Chroma. That's because of the detail in the green color channel that digital cameras retain. Additionally, green screens typically require less light to properly illuminate (Driscoll, 2019).

Moreover, here, at this point in history, the influence that journalism had on the analyzed technology of shooting is most noticeable. The use of blue cloth for Chroma key became difficult because guests who came to the studio as spectators or for interviews massively began to wear blue jeans. And, when the technician began to remove all blue color from the frame, people's legs "disappeared".

Blue and green are not the only (although they are the most popular because there are no such skin tones) colors that have been used. There are examples in history when red, white, yellow, and even black cloth was used. For example, in 1903, the film "The Great Train Robbery" directed by E. Porter was released, where a double exposure was used to create a background in the train windows, which were covered with a black cloth during the filming (Ramey, 2015). In the 1920s, W. Disney used a white background in the "Alice Comedies" movie series to combine the image of live actress with painted character - the cat Julius (Foster, 2010).

The Chroma key came to journalism from cinematography, but in turn, journalism also gave a lot to cinema. It was the mobility and speed with which journalists should work that brought its own corrections. Therefore, bilateral portable Chroma key appeared. If it is urgent to interview a person in blue clothes, the journalist exposes a green cloth. Vice versa, if there should be a person in the frame who is dressed in something green, the journalist simply turns the cloth over with the other - blue - side.

So, what should a journalist know and be able to do?

Item 1. One of the first is deciding if you should use a green screen or blue screen. On today's digital cameras, green will likely give you the cleanest key. However, if your guest has blonde hair or green clothing, you'll likely have better results with a blue screen as green can spill into light-colored hair (Yeager, 2019). It's better to clarify the new term closely related to this technology right away.

Spill: this often refers to the colored light that reflects back onto your subject from the green screen. When a green screen is brightly lit, the light can actually reflect that color back onto your subject. There are a number of steps you can take to prevent spill (Driscoll, 2019). But we will not stop on this in detail, because these points concern mainly technical specialists. All that is necessary for a journalist who plans such a shooting is to have a white bed sheet with him, it can be mounted on a stand a few feet in front of the light.

Item 2. Obviously, avoid green. Journalists shouldn't wear green or its shades transparent in the key. You should also avoid shiny objects (such as large earrings, rings, chains, pendants, jewelry with stones, etc.), as these can reflect the green and cause transparent spots. If reflective objects must be used, you will likely have to manually mask around those objects in post-production. This can be very time consuming, so plan ahead if that is ultimately required (Yeager, 2019). The greatest difficulties are brought by translucent objects, such as individual curls of hair, transparent raincoats or umbrellas, glass. If possible, it is better to avoid such things. In addition, because of the individual curls, it is best for women to collect their hair in a ponytail or do styling with a strong fixation.

Item 3. Use a non-reflective green screen material and look for colors such as "chroma key green" and "digi green." These colors are toned to be ideal for use with green screens. Alternatively, blue screens can also be used, especially for replicating 
night scenes (Yeager, 2019). At the same time, the journalist should know that he may need an iron, regardless of what color cloth will be used. Smooth folds without wrinkles greatly facilitate the keying process, especially if the journalist himself does the installation.

Always use gloves when handling the green screen. The curtain must remain as clean as possible for optimal function (BCIT, 2020).

If you work alone in the studio and constantly shoot with a Chroma key, there is such an option as painting the wall in green. But, cloth continues to be a leader in this technology for a number of reasons. Using a green or blue cloth is more versatile still. The material is inexpensive, can be folded away in between sessions, and can even be wrapped around stage elements such as broadcasting desks or uneven walls. The only downsides to using cloth is that any creases or wrinkles can cause shadows, and the resulting uneven color tones can be harder to work around in the editing suite (Zeke, 2014).

Item 4. If you are planning complex composite shooting, your main goal is to determine what is real and what is not in your scene. This means you want to know what will physically be in the scene, and what will be added in later during post-production. In certain cases, you may need real props on set that yourself and your guests can reference. To do this, foreign journalists and directors often use ordinary tennis balls, which are suspended on a fishing line. These provide visual reference points. Professional operators as references also use the red crosses from the insulating tape. These crosses help the correct smooth movement of the camera. This is the videographer's job, but the journalist should know this.

Item 5. Avoid standing too close to the screen to minimize green reflection on your skin (BCIT, 2020). Make sure to light the background as evenly as possible, with no hot spots. Second, it helps to stand the subject as far away from the backdrop as possible to separate the two. This helps to reduce spill from the lights illuminating the journalist into the lighting on the green screen. It's probably a more exaggerated shadow than you'd want were the talent properly lit and standing on a real set. But it can go far in providing that suspension of disbelief. That helps the viewer accept that a Chroma shot is working (Driscoll, 2019).

Item 6. You need to think through all aspects in advance before shooting. One of the important ones may be artificial or natural shadow. Drop Shadow effect strongly related to this. We again explain the new term.

Drop Shadow: as it sounds, the drop shadow feature adds an artificial shadow into the background from the journalist (with additional settings allowing you to specify the direction). This can look odd in some Chroma key features, but it can also make the scene more natural - as with all Chroma key settings, there's no harm in playing around until you gain optimal results (Zeke, 2014).

Item 7. A true journalism professional should always know where to buy or rent everything you need to shoot using Chroma key technology. He must know the prices and delivery times. Therefore, it is best to collect information about sellers and property owners in your city in advance.

\section{Conclusion}

Essentially, if you've done everything right you've chosen the right Chroma color, exposed correctly, shot against a clean screen, and chosen the highest possible compression format you can - you should be able to isolate your Chroma color in one click when you begin the post process (Renee, 2015). In order to make that one click, a lot of preliminary preparation is necessary, both technically and creatively. In turn, for this preparation to go quickly and smoothly, knowledge is needed.

Provided that all members of the crew or the editorial team have such knowledge, the work will go much faster and easier. In the near future, work in this format will become more and more popular.

Nowadays, this shooting technology is very common in all areas. According to the data, almost every big movie made in 2019 used Green Screen effects for at least one scene (Driscoll, 2019). There are no such statistics in journalism, but we can judge how often the Green Screen is used already by the fact of its presence in everyday media content.

\section{References}

Backdrop Express Photography Team. (25.10.2013). What do you need a green man suit for? Green Screens, Photography Tips. Retrieved from http://blog.backdropexpress.com/what-do-you-need-a-green-man-suit-for/.

BCIT. News manual. Green screen filming. Retrieved from http://bcitnews.com/manual/green-screen-shoot/.[17.04.2020].

Chromakeysuit.com. Green screen suits and blue screen suits for demanding video professionals. Retrieved from https://www. chromakeysuit.com/. [15.04.2020]. 
Driscoll, E. (2019). The keys to Chroma key: how to use a green screen. Videomaker. Retrieved from https://www.videomaker. com/article/f5/13055-the-keys-to-chromakey-how-to-use-a-green-screen.

Foster, J. (2010). The Green Screen Handbook: Real-World Production Techniques. - John Wiley \& Sons. - 384 p.

Higgins, P. (15.09.2017). Who invented the Green Screen? Our Pastimes. Retrieved from https://ourpastimes.com/who-invented-the-green-screen-12195492.html.

Joan, B. (31.05.2012). Difference between Chroma key and Green Screen. DifferenceBetween.net. Retrieved from http://www. differencebetween.net/technology/web-applications/difference-between-chroma-key-and-green-screen/.

Marshall, S. (03.01.2013). 10 things every journalist should know in 2013. Journalism. Co.uk. Retrieved from https://www. journalism.co.uk/news/10-things-every-journalist-should-know-in-2013/s2/a551648/.

MediaCollege.com. Chroma Key. Glossary. Retrieved from https://www.mediacollege.com/glossary/c/chroma-key.html. [14.04.2020].

Ramey, K. (2015). Experimental filmmaking: break the machine. - CRC Press. - 404 p.

Redbubble.com. Green Screen A-Line dress. Retrieved from https://www.redbubble.com/i/dress/Green-Screen-by-ThornerUA/46515656.V4WQ8. [17.04.2020].

Renee, V. (30.09. 2015).5 Secrets to pulling of a Hollywood-level Chroma key (besides good lighting). No Film School. Retrieved from http://www.differencebetween.net/technology/web-applications/difference-between-chroma-key-and-green-screen/ https://nofilmschool.com/2015/09/5-secrets-pulling-hollywood-level-chroma-key-besides-good-lighting.

Satu.kz. (14.04.2020). Каталог товаров - [Catalog]. Retrieved from https://satu.kz/Hromakej.html.

Streamingvalley.nl. Chromakey Corner. Retrieved from https://www.streamingvalley.nl/product/chromudio-chromakey-cmcorner/.

Voroisky, F (2016). Информатика. Энциклопедический словарь-справочник - [Computer science. Encyclopedic Dictionary]. Litres. P. 413.

Yeager, Ch. (29.07. 2019). Everything you need to know about chroma key and green screen footage. Premium Beat. Retrieved from https://www.premiumbeat.com/blog/chroma-key-green-screen-guide/.

Zeke, S. (08.07.2014). Improving a broadcast journalism project with Chroma keying. New York Film Academy. Student Resources. Retrieved from https://www.nyfa.edu/student-resources/improving-broadcast-journalism-project-chroma-keying/. 


\title{
A.B. Alzhanova , Y.M. Sajjad iD , A.Anarbek iD , G.S. Seraliyeva \\ Al-Farabi Kazakh National University, Kazakhstan, Almaty, e-mail: aljanova.aigerim@gmail.com; e-mail: sajjadyasa@live.com; e-mail: adina.anarbek@gmail.com; e-mail: seraliyeva.gulden@gmail.com
}

\section{USAGE OF STATISTICS IN STUDENT RESEARCH WORK}

The relevance of the topic is due to the demand for statistical processing of experimental data in the preparation of research work. Students often have difficulty analyzing a large amount of data. However in order to analyze the data for practical purposes, it is not necessary to be fluent in mathematical formulas, probability theory, or mathematical analysis. There are various types of programs that can be utilized without in-depth knowledge of the applied mathematics.

The purpose of the article is to present methods of statistical processing of information, the main directions of the use of data in student research papers. The authors of the article introduce the types of research in the field of statistics, give examples for each of them. They consider where the data comes from, how they receive the data, what they look for in the data, how to process the data, and how best to work with the results. The main direction of scientific research is a description of skills, the process of building a model, the applied software and algorithmic tools, the possibility of using various statistical data processing programs.

The research methodology is based on the concepts of domestic and foreign researchers, who have a scientific platform, based on the principles of objectivity, concreteness. The value of this work is that students will learn to use these statistical methods in their research, develop a research methodology, process and interpret data, and correctly use the results.

Key words: statistical method, data processing, statistical research; student studies; statistical data processing.

\author{
А.Б. А^ьжанова, Я.М. СалжаА, А. Анарбек, Г.С. Сералиева \\ Әл-Фараби атындағы Қазақ ұлттық университеті, Қазақстан, Алматы қ., \\ e-mail: aljanova.aigerim@gmail.com, e-mail: sajjadyasa@live.com; \\ e-mail: adina.anarbek@gmail.com, e-mail: seraliyeva.gulden@gmail.com
}

\section{Студенттердің зерттеу жұмысында статистика әдісін қомдануы}

Тақырыптың өзектілігі ғылыми-зерттеу жұмыстарын дайындауда тәжірибелік мәліметтерді статистикалық өңдеуге деген сұранысқа байланысты. Студенттер көбінесе үлкен көлемді деректерді талдауда қиындық көреді. Бірақ деректерді практикалық мақсатта талдау үшін математикалық, формулаларды, ықтима^дықтар теориясын немесе математикалық анализді еркін меңгерудің қажеті жоқ. Жұмыс кезінде қолданылатын математиканың мәніне терең үңілмей-ақ, қолдануға болатын түрлі бағдарламалар бар.

Мақаланың мақсаты - ақпаратты статистикалық өңдеу әдістерін, студенттердің ғылыми жұмыстарында мәліметтерді қолданудың негізгі бағыттарын ұсыну. Мақала авторлары статистика саласындағы зерттеулердің түрлерін ұсынады, олардың әрқайсысына мысалдар келтіреді. Олар деректердің қайдан алынғанын, оларды қалай қабылдайтынын, деректерді қалай іздейтінін, деректерді қалай өңдеуді және нәтижелермен қалай дұрыс жұмыс істеуді қарастырады. Ғылыми зерттеудің негізгі бағыты - дағдыларды сипаттау, үлгіні құру процесі, қолданбалы бағдарламалық, жасақтама және алгоритмдік құра^дар, мәліметтерді өңдеудің әртүрлі бағдарламаларын қолдану мүмкіндігі.

Зерттеу әдістемесі ғылыми платформасы бар, объективтілік, нақтылық принциптеріне негізделген отандық және шетелдік зерттеушілердің тұжырымдамаларына негізделген. Бұл жұмыстың құндылығы студенттердің зерттеу барысында осы статистикалық әдістерді қолдануды, зерттеу әдістемесін жасауды, деректерді өңдеуді және түсіндіруді, нәтижелерді дұрыс пайдалануды үйренеді.

Түйін сөздер: статистикалық, әдіс, мәліметтерді өңдеу, статистикалық зерттеулер, студенттік оқу, статистикалық мәліметтерді өңдеу. 